\title{
Sustainability indicators for electric power generation assessment in Indonesia using snowballing method environment, social, and economic dimension
}

\author{
Adam Wicaksono ${ }^{1}$, Ahyahudin Sodri ${ }^{1 *}$, and Ellyna Chairani ${ }^{1}$ \\ ${ }^{1}$ School of Environmental Science, Universitas Indonesia. UI Salemba Campus, Central Jakarta \\ 10430, Indonesia
}

\begin{abstract}
Indonesia's power generation capacity increased by $3 \%$ to reach $64.5 \mathrm{GW}$ from 20017 to 2018 , where $86 \%$ of the power plants that have been built are fossil-fueled. Limited resources and the impact arising from the production process will impact the environment, thus hindering sustainable development. Therefore, it is needed to set indicators that can be used to evaluate power generation's sustainability to improve the community's welfare. This research aims to find sustainability indicators that can be used to assess the electrical power generation system. A total of 51 articles from the snowball sampling approach was analyzed using a qualitative systematic literature review and quantitative method. We found 43 indicators covering economic, social, and environmental dimensions that can be used to assessed Indonesia's electrical power generation's sustainability.
\end{abstract}

\section{Introduction}

The increasing population growth and economic growth in line with industrial developments will encourage an increase in energy demand [1]. Electrical energy is the most fundamental need in today's modern era. Electrical power is needed in various lifelines, from government, trade, household, and even recreation areas, which also depend on the presence of electricity because of the ease with which electrical energy can be converted into other forms [2]. The demand for electrical power is expected to continue to increase. For decades, global consumption of electrical energy has grown fastest compared to the consumption of other energies. In Indonesia, the consumption of electrical energy in Figure 2 shows that electricity is enormous after fuel, namely 156.98 Million BOE [3]. Global electricity generation is predicted to increase by $69 \%$ in 2040 . Compared to 2012 , electricity generation in 2012 was 21.6 trillion kilowatt-hours $(\mathrm{kWh})$ to be 36.5 trillion kWh by 2040 [4].

Meanwhile, in Indonesia, the growth in demand for electrical energy is expected to increase until 2050. Indonesia's power generation capacity in 2018 reached $64.5 \mathrm{GW}$ or an

* Corresponding author: ahyahudin.sodri@ui.ac.id 
increase of 3\% compared to the 2017 total [5]. Although in 2019, power generation growth decreased by only $1.3 \%$, about half of the 10 -year average [6]. Currently, based on the source, electricity generation is still dominated by fossil fuels, especially coal. However, starting in the early 2000s, there was increasing concern about the greenhouse gas emissions effect, so the development and use of new and renewable energies continued to increase. However, the contribution of renewable energy in the global energy mix is still at $5 \%$ in 2019 [4]. The installed capacity of power plants in Indonesia in figure 2 in 2018, which reached $64.5 \mathrm{GW}$. The established power plants are mostly dominated by fossil fuel power plants $(86 \%)$, consisting of coal, gas, and oil. The rest is a renewable electrical generation (14\%), consisting of hydro, micro-hydro, mini-hydro, geothermal, wind, diesel, waste, biomass, and biogas [5].

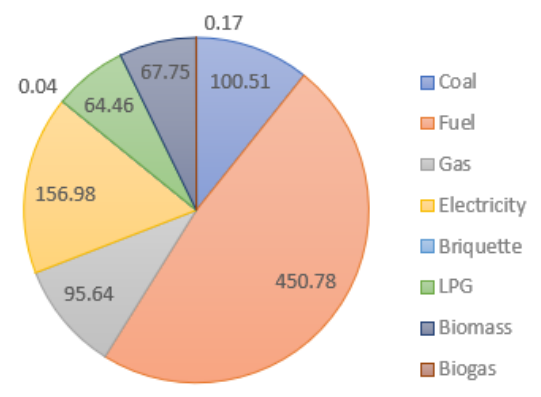

Fig. 1. Energy Consumption by Type in Million BOE [3].

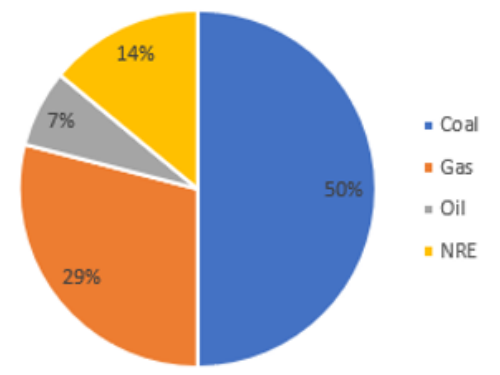

Fig. 2. Installed capacity of power plants based on energy Sources in 2018 [3].

The electrical energy that continues to increase and technological developments in various lines requiring electrical energy as a driving force makes electrical energy vital to human life today [2], [7]. The importance of electrical energy and the development of various types of power plants, the competitive price of production costs, and each power plant's impact encourage policymakers to evaluate how a sustainable generator's performance is integrated. The concept of sustainability is defined as a condition where the fulfillment of current needs does not interfere with future needs [2], [8], [9]. Therefore, to improve the sustainability of the people's welfare, both from the economic and environmental conditions, more sustainable energy options must be identified and pursued. Sustainable energy cannot be done if no indicator can evaluate a comparison tool that policymakers can use. The indicators used to evaluate power plants should include the three sustainability dimensions: the social economy and the environment. In a conventional power plant, environmental impact assessments usually only assess the power plant's impacts during the operation period. So it is assumed that impacts that occur in the 
upstream and downstream parts such as fuel extraction, transportation, or distribution of electricity to customers are not part of the power generation process's responsibility. Environmental impacts arising from the construction, commissioning, decommissioning, and demolition processes are usually ignored. The life cycle perspective, the processes that occur from the cradle to the grave, or raw material extraction to the product's use and disposal are essential in seeing a broader and more comprehensive perspective [10]. Life cycle assessment (LCA) has become the most widely used methodology for evaluating environmental sustainability [9].

The snowballing method is chosen because of the advantage of the technique. It can find literature that fits the research topic more quickly and more effectively because the investigation is carried out in a systematic and focused manner to reduce the time used to avoid literature that is not related to the research topic. The purpose of this article is to identify relevant indicators to be applied so that they can be used to assess the sustainability of existing power plants, especially in Indonesia, from the three dimensions of sustainability using the life cycle perspective. Furthermore, this indicator can be used as a framework that can be used to assess the sustainability of power plants, considering the general economic, environmental, and social dimensions of sustainable development that apply to various power generation options and mixes.

\section{Method}

The method used in this study is a systematic qualitative literature review method with a snowballing approach. A systematic review is recommended because it is a rigorous and verifiable methodology, reducing the possibility of bias from the study results [11], [12]. In a systematic literature review study carried out using specific guidelines to reduce bias. Figure 3 is a research step carried out; the first is to determine the research objectives. The second defines the keywords and databases that will be used as the research population. The third is selecting a paper deemed appropriate to the research topic based on the title and abstract to be the key paper for the research to be carried out. The fourth is doing a search using the snowballing approach (SB). The snowballing method is carried out by finding documents related to the topic being researched from the key papers that have been carried out by browsing the bibliography of key papers relevant to the research being carried out. This method's advantage is that it can find literature that fits the research topic more quickly and more effectively because the investigation is carried out in a systematic and focused manner to reduce the time used to avoid literature that is not related to the research topic. This method's disadvantage is that every source found will be older than the previous one due to retrospective searches.

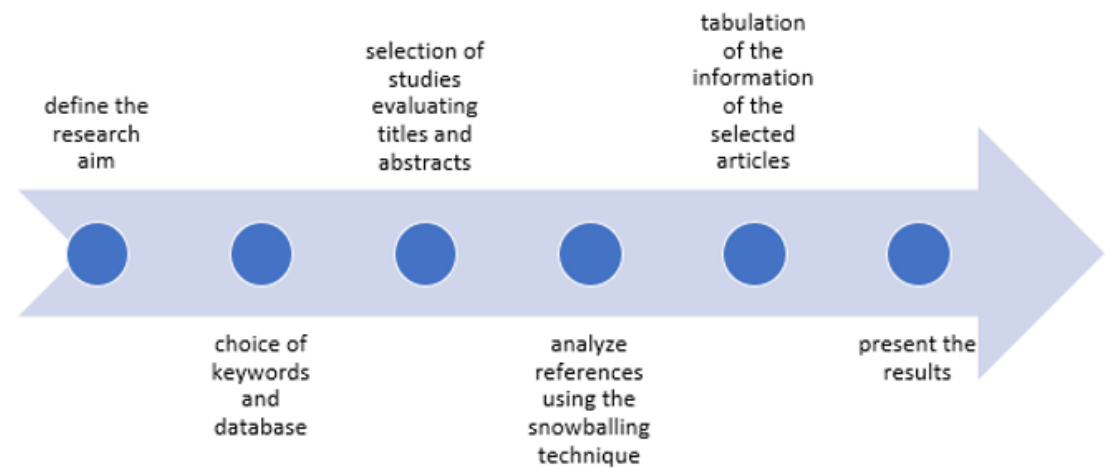

Fig. 3. Research stages. 
This study aims to determine the indicators of the sustainability of the power plant. The keywords used as the basis are "Sustainability indicators" and "Power Generation" in English because $85 \%$ of scientific publications in the world are published in English [11]. Keywords are applied to the reference journal database with double quotes, so each title must have all word expressions in its full text, not only in titles or abstracts. So that obtained in Scopus as many as 51 articles were conducted in September 2020. Based on the title and abstract's relevance, five journals were considered most relevant to the research objectives. To ensure the relevance and reliability of the articles used, a source that has credibility in this study was chosen Scopus. The type of publication chosen is a journal article or book chapter. Other considerations that need to be considered are the author, the citation source, and how often the piece is cited. The initial set of publications carried out, then backward snowballing was carried out [13]. After all, indicators that can be used are found. The author follows [11] to calculates the average number of indicators used in each journal and then calculates the coefficient of variation of the number of indicators in each dimension to determine the dispersion level precision.

Table 1. Guideline and Compliance in Snowballing [13].

\begin{tabular}{|l|l|}
\hline \multicolumn{1}{|c|}{ Guideline } & \multicolumn{1}{c|}{ Compliance } \\
\hline $\begin{array}{l}\text { The papers to start set should not refer to each } \\
\text { other. }\end{array}$ & Five papers are not referring to each other. \\
\hline $\begin{array}{l}\text { The start set must cover different publishers, } \\
\text { different years, and various authors. }\end{array}$ & $\begin{array}{l}\text { The start set papers from different years, } \\
\text { different publisher, and various author }\end{array}$ \\
\hline $\begin{array}{l}\text { The number of papers collected must be } \\
\text { reasonable; the more specific the research theme } \\
\text { will require a smaller number of papers. }\end{array}$ & $\begin{array}{l}\text { The number of papers depends on the } \\
\text { research theme. In this study, the authors } \\
\text { believe the number of documents selected is } \\
\text { enough to be used as an initial set in the } \\
\text { snowballing technique. }\end{array}$ \\
\hline $\begin{array}{l}\text { The start set must be formulated from keywords in } \\
\text { the research questions. }\end{array}$ & $\begin{array}{l}\text { The search strings were formulated using } \\
\text { keywords in the research questions. }\end{array}$ \\
\hline
\end{tabular}

\section{Results and discussion}

Based on the search patterns that have been determined in the dietary method section, five publications will be used as the initial set in Table 2. The initial sets were selected based on different authors' names, other years, and various sources. Also, the number of cites is considered based on the number of cites. Then see the application of the LCA application in the journal. Then, based on the initial data set, the search was developed and expanded by applying Backward Snowballing (BS). Based on the application of BS then obtained 30 different publications even though there are the same authors in several journals. BS means using the reference list to identify new papers for inclusion. The trick is to look at the title on the reference list following the research theme by considering the type of publication. If necessary, it can also include author, publisher, and year of publication as a consideration. Then the abstract is evaluated, and candidate papers that do not meet the criteria are issued. This is done so that there are no more publications where it is possible to retrieve the information. Besides, researchers can also read the contents of the paper if needed. Publications found from 30 publications were then reduced because the contents were deemed not to have answered the research objectives, so that 24 articles were considered the most answering the research objectives. 
Table 2. Initial sets for snowballing.

\begin{tabular}{|c|c|c|c|c|}
\hline Authors & Year & Case Study & Source & $\begin{array}{c}\text { Using Life } \\
\text { Cycle Method }\end{array}$ \\
\hline $\begin{array}{l}\text { Atilgan, } \\
\text { B., Azapagic, A. [9] }\end{array}$ & 2016 & $\begin{array}{l}\text { Electric Power } \\
\text { Generation in Turkey }\end{array}$ & Energy Policy & Yes \\
\hline $\begin{array}{l}\text { Onat, N., Bayar, } \\
\text { H.[14] }\end{array}$ & 2010 & $\begin{array}{l}\text { Electric Power } \\
\text { Generation }\end{array}$ & $\begin{array}{l}\text { Renewable and } \\
\text { Sustainable Energy } \\
\text { Reviews }\end{array}$ & No \\
\hline $\begin{array}{l}\text { Akber, } \\
\text { M.Z., Thaheem, } \\
\text { M.J., Arshad, } \\
\text { H.[15] }\end{array}$ & 2017 & $\begin{array}{l}\text { Electric Power } \\
\text { Generation in } \\
\text { Pakistan }\end{array}$ & Energy Policy & Yes \\
\hline Khan, I.[16] & 2019 & $\begin{array}{l}\text { Electric Power } \\
\text { Generation in } \\
\text { Development Country }\end{array}$ & $\begin{array}{l}\text { Journal of Cleaner } \\
\text { Production }\end{array}$ & No \\
\hline $\begin{array}{l}\text { May, J.R., Brennan, } \\
\text { D.J.[10] }\end{array}$ & 2006 & $\begin{array}{l}\text { Electric Power } \\
\text { Generation in } \\
\text { Australia }\end{array}$ & $\begin{array}{l}\text { Process Safety and } \\
\text { Environmental } \\
\text { Protection }\end{array}$ & Yes \\
\hline
\end{tabular}

The results of these searches show the use of sustainability indicators in power generation with various technologies used. Another thing that can be found is that there are various methods for determining policies and evaluating various types of power plants' sustainability conditions. The method, such as multicriteria decision analysis and Life cycle assessment is developed into a life cycle sustainability assessment method. It is widely recognized and accepted that sustainability assessment should take a life cycle approach, considering all relevant economic, environmental, and social sustainability [2]. Therefore, the summary of the indicators proposed here will take this into account. Based on the results of the research conducted by the author, it is summarized in Table 3.

Table 3. Sustainability characteristics indicators.

\begin{tabular}{|c|c|c|c|c|c|c|c|c|}
\hline \multirow[t]{2}{*}{ No } & \multirow[t]{2}{*}{ Authors } & \multirow[t]{2}{*}{ Year } & \multirow{2}{*}{$\begin{array}{c}\text { Total } \\
\text { Indicator }\end{array}$} & \multicolumn{4}{|c|}{ Indicator } & \multirow{2}{*}{$\begin{array}{l}\text { Using } \\
\text { LCA }\end{array}$} \\
\hline & & & & Eco & Soc & Enviro & Other & \\
\hline 1 & Khan, I.[16] & 2019 & 19 & 5 & 10 & 4 & & No \\
\hline 2 & $\begin{array}{l}\text { Akber, } \\
\text { M.Z., Thaheem } \\
\text {, M.J., Arshad, } \\
\text { H.[15] }\end{array}$ & 2017 & 20 & 5 & 4 & 11 & & Yes \\
\hline 3 & $\begin{array}{l}\text { Atilgan, } \\
\text { B., Azapagic, } \\
\text { A.[9] }\end{array}$ & 2016 & 20 & 3 & 6 & 11 & - & Yes \\
\hline 4 & $\begin{array}{l}\text { Onat, } \\
\text { N., Bayar, } \\
\text { H.[14] }\end{array}$ & 2010 & 8 & & & & & $\begin{array}{l}\text { Not } \\
\text { Specified }\end{array}$ \\
\hline 5 & $\begin{array}{l}\text { May, } \\
\text { J.R., Brennan, } \\
\text { D.J.[10] }\end{array}$ & 2006 & 21 & 5 & 4 & 12 & & Yes \\
\hline 6 & $\begin{array}{l}\text { Al Garni, H., et } \\
\text { al.[17] }\end{array}$ & 2016 & 36 & 12 & 7 & 6 & 11 & No \\
\hline 7 & $\begin{array}{l}\text { Jeswani, et } \\
\text { al.[18] }\end{array}$ & 2011 & 7 & 2 & & 5 & & Yes \\
\hline 8 & $\begin{array}{l}\text { Evans, et } \\
\text { al.[19] }\end{array}$ & 2009 & 7 & & & & & Yes \\
\hline 9 & $\begin{array}{l}\text { Gujba, H., et } \\
\text { al.[20] }\end{array}$ & 2010 & 13 & 3 & & 10 & & $\begin{array}{l}\text { Not } \\
\text { Applied }\end{array}$ \\
\hline
\end{tabular}




\begin{tabular}{|c|c|c|c|c|c|c|c|c|}
\hline 10 & $\begin{array}{l}\text { Štreimikiene, } \\
\text { D., et al.[21] }\end{array}$ & 2016 & 20 & 4 & 3 & 4 & 9 & $\begin{array}{l}\text { Not } \\
\text { Applied }\end{array}$ \\
\hline 11 & $\begin{array}{l}\text { Chatzimouratid } \\
\text { is, A. I., \& } \\
\text { Pilavachi, P. } \\
\text { A.[22] }\end{array}$ & 2009 & 9 & & & & & No \\
\hline 12 & $\begin{array}{l}\text { Hirschberg, S., } \\
\text { et al.[23] }\end{array}$ & 2004 & 13 & 2 & 6 & 5 & & Yes \\
\hline 13 & $\begin{array}{l}\text { Klein, S. J. W., } \\
\text { \& Whalley, S. } \\
\text { [24] }\end{array}$ & 2015 & 8 & 1 & 2 & 4 & 1 & Yes \\
\hline 14 & $\begin{array}{l}\text { Rovere, et } \\
\text { al.[25] }\end{array}$ & 2010 & 15 & 3 & 3 & 5 & 4 & No \\
\hline 15 & $\begin{array}{l}\text { Genoud, S., \& } \\
\text { Lesourd, J. B. } \\
{[26]}\end{array}$ & 2009 & 12 & 5 & 6 & 1 & & No \\
\hline 16 & $\begin{array}{l}\text { Rodríguez- } \\
\text { Serrano, I., et } \\
\text { al.[27] }\end{array}$ & 2017 & 16 & \multicolumn{2}{|c|}{10} & 6 & & Yes \\
\hline 17 & $\begin{array}{l}\text { Dorini, et } \\
\text { al.[28] }\end{array}$ & 2010 & 22 & \multicolumn{2}{|c|}{9} & 13 & & Yes \\
\hline 18 & Maxim[29] & 2014 & 10 & 4 & 4 & 2 & & Yes \\
\hline 19 & $\begin{array}{l}\text { Wang, J. J., et } \\
\text { al.[30] }\end{array}$ & 2009 & 29 & 9 & 4 & 9 & 7 & Yes \\
\hline 20 & $\begin{array}{l}\text { Meyar-Naimi, } \\
\text { H., \& Vaez- } \\
\text { Zadeh, S.[31] }\end{array}$ & 2013 & 25 & 5 & 5 & 5 & 10 & No \\
\hline 21 & $\begin{array}{l}\text { Kowalski, K., } \\
\text { et al.[32] }\end{array}$ & 2009 & 17 & 1 & 12 & 4 & & No \\
\hline 22 & $\begin{array}{l}\text { Stamford, L., } \\
\text { \& Azapagic, } \\
\text { A.[2] }\end{array}$ & 2011 & 43 & 13 & 19 & 11 & & Yes \\
\hline 23 & $\begin{array}{l}\text { Stamford, L., } \\
\text { \& Azapagic, } \\
\text { A.[33] }\end{array}$ & 2014 & 36 & 12 & 14 & 10 & & Yes \\
\hline 24 & $\begin{array}{l}\text { Santoyo- } \\
\text { Castelazo, E., } \\
\text { \& Azapagic, A. } \\
\text { [7] }\end{array}$ & 2014 & 17 & 3 & 4 & 10 & & Yes \\
\hline
\end{tabular}

Based on the results of Table 3, it shows that the number of indicators used is inconsistent from each study. The average number of indicators used is 18 indicators; apart from that, each aspect's distribution tends to be fluctuating and not the same. Analysis of the total number of indicators and based on each dimension shows inconsistent arithmetic mean; the calculation of the coefficient of variation has a value higher than 0.6 , indicating high dispersion and low precision [11]. The use of LCA in the sought paper reached $56 \%$ of the 24 papers that presented sustainability indicators. The indicator set is flexible, allowing indicators to be added (or removed) if an existing set proves to be inadequate [10]. Also, the paper describes, more specifically, the boundaries of the study system, which includes regions, countries, specific technologies. Besides that, the time horizons used are different; the assessment method does not only cover LCA, and the procedures for integrating sustainability considerations also vary. The integration of sustainability indicators is carried out in most studies, using multi-attribute value theory, hierarchical analytic process, and weighted sum. 
Based on these findings, the author found the indicators of sustainability indicators used in previous studies. In Table 4, the authors summarize the indicators that have been used in several countries to evaluate the conditions of various types of power plants from the papers found. The findings are expected to be adopted in Indonesia.

Table 4. Sustainability Indicator for electricity generation.

\begin{tabular}{|c|c|c|c|}
\hline No & Dimension & Sustainability Indicator & Reference \\
\hline 1 & Environment & $\begin{array}{l}\text { Global warming, acidification, eutrophication, freshwater } \\
\text { aquatic ecotoxicity, abiotic depletion, human toxicity, } \\
\text { marine aquatic ecotoxicity, ozone depletion, summer smog, } \\
\text { and terrestrial ecotoxicity, recyclability of input material, } \\
\text { land occupation, greenfield land use, external costs, the } \\
\text { ecological impact of zinc, resource depletion, water } \\
\text { consumption, air pollution, solid waste, particulates matter } \\
\text { and mercury emissions, accidental hydrocarbon spills, } \\
\text { radioactivity, threatened species, ionizing radiation }\end{array}$ & \multirow[t]{3}{*}{$\begin{array}{l}{[2],[7],[9],} \\
{[10], \quad[15],} \\
{[19], \quad[23],} \\
{[24], \quad[27]-} \\
{[30],[33]}\end{array}$} \\
\hline 2 & Social & $\begin{array}{l}\text { Security and diversity supply, public acceptability, health } \\
\text { and safety, intergenerational issues, provision of } \\
\text { employment, local community impact, human right and } \\
\text { corruption, energy security, nuclear proliferation, social } \\
\text { benefit, social acceptability, external supply risk }\end{array}$ & \\
\hline 3 & Economic & $\begin{array}{l}\text { Capital costs, annualized costs, Levelized costs, fuel cost, } \\
\text { electric cost, Net Present Value (NPV), Payback Period, } \\
\text { value-added }\end{array}$ & \\
\hline
\end{tabular}

The environmental indicators collected are indicators from papers that adopt LCA analysis. LCA analysis was also carried out in studies in the same field in Turkey [9], UK [2], Australia [10], Mauritius [34], and Portugal [35]. Indonesia currently has introduced the LCA model to be applied in the industry through government regulations [36]. The included social and economic indicators are also the findings of a paper that implements the LCA approach in their research. In publications that describe this sustainability indicator, apart from using the three pillars of sustainability, some journals include technological dimensions [29], technical [30], or a combination of dimensions such as socio-economic [28], socio-political [29], and techno-economic [2], [33]. However, the authors refer to the three pillars of sustainability to reduce indicators on dimensions outside sustainability. Also, the number of indicators used does not have a particular reference number adjusted to the implementation conditions and visibility. In this study, the authors regroup the found indicators into three sustainability dimensions and reduce indicators with the same definition and operation. As the results, it is obtained for the environmental dimensions 24 indicators, 12 social dimensions indicators, and seven economic dimensions indicators with a total number of indicators 43 indicators.

This study proposes indicators that can be used to assess the sustainability of the generating system in Indonesia with a life cycle approach. These indicators result from a qualitative approach, namely the author's judgment, who are practitioners in the field of generation. So that there is an element of subjectivity from the author in grouping and determining these indicators. To the best of the authors' knowledge, no research has been found that has developed sustainability indicators to evaluate Indonesia's power plants that integrate three sustainability dimensions. Therefore, this research contributes by providing a reference for assessing power plants' sustainability with a life cycle approach, specifically in Indonesia, by considering socio-economic and environmental conditions. Furthermore, this study's results can also be used as a reference because the proposed indicators have been applied by previous researchers in other countries so that they are also visible to be applied in Indonesia. However, these indicators still need to be further developed with a 
quantitative approach to be generalized. In this research, several deficiencies are expected to be developed for further research, namely using the snowballing method with forwarding SB and backward SB to obtain more information. Besides, it can involve input from stakeholders combined with literature reviews to be more visible to be applied and accepted in determining indicators.

\section{Conclusion}

This study aims to describe the trends in the use of indicators by researchers to operationalize a power plant's sustainability assessment. Over time, we found that the indicators expanded; this was influenced by various plant operational practices and community dynamics. We also find that these indicators are built on stakeholder perspectives. Furthermore, this study contributes to the literature of power-plant sustainability assessment by proposing 43 indicators, including economic, social, and environmental dimensions. This study's proposed indicators could also be used for the Cycle Assessment (LCA) of electrical power-plant, especially in Indonesia. Based on the results and discussion above, it can be concluded that the snowballing method is useful and relevant for finding literature that is under the research topic being studied and increases the effectiveness of the research time depend on conventional literature review. It is practically crucial to formulate indicators to evaluate a system's performance to be considered by policymakers. The number of indicators in determining sustainability does not have standard rules depending on the knowledge and preference of formulator and stakeholders; besides that, it must also consider data visibility and data collection time.

\section{Acknowledgements}

This research is funded by the Grant of Indexed International Publication for Master Student (PUTI Q4) Universitas Indonesia 2020 with contract number: NKB2575/UN2.RST/HKP.05.00/2020.

\section{References}

1 A. Karapekmez and I. Dincer, Appl. Therm. Eng. 164, 114409 (2020)

2 L. Stamford and A. Azapagic, Energi 36, 6037 (2011).

3 ESDM, Handbook Of Energy \& Economic Statistics Of Indonesia 2018 Final Edition, (Ministry Energy Minera Resource, 2018).

4 US Energy Information Administration, Int. Energy Outlook, 81 (2016).

5 Suharyati, P. S. Hesti, J. L. Wibowo, and N. I. Pratiwi, Indonesia Energy Outlook, (Jakarta, 2019).

6 BP, Statistical Review of World Energy 2020, 66 (2020).

7 E. Santoyo-Castelazo and A. Azapagic, J. Clean. Prod. 80, 119 (2014).

8 WCED, Report of the World Commission on Environment and Development: 'Our Common Future, (1987).

9 B. Atilgan and A. Azapagic, Energy Policy 93, 168 (2016).

10 J. R. May and D. J. Brennan, Process Saf. Environ. Prot. 84, 131 (2006).

11 A. A. Feil, D. Schreiber, C. Haetinger, V. J. Strasburg, and C. L. Barkert, Sustain. 11, 1 (2019).

12 R. S. Wahono, J. Softw. Eng. 1, 1 (2015).

13 C. Wohlin, Guidelines for Snowballing in Systematic Literature Studies and a Replication in Software Engineering, (2014). 
14 N. Onat and H. Bayar, Renew. Sustain. Energy Rev. 14, 3108 (2010).

15 M. Z. Akber, M. J. Thaheem, and H. Arshad, Energy Policy 111, 111(2017).

16 I. Khan, J. Clean. Prod. 220, 707 (2019).

17 H. Al Garni, A. Kassem, A. Awasthi, D. Komljenovic, and K. Al-Haddad, Sustain. Energy Technol. Assessments 16, 137 (2016).

18 H. K. Jeswani, H. Gujba, and A. Azapagic, Waste and Biomass Valorization 2, 33 (2011).

19 A. Evans, V. Strezov, and T. J. Evans, Renew. Sustain. Energy Rev. 13, 1082 (2009).

20 H. Gujba, Y. Mulugetta, and A. Azapagic, Energy Policy 38, 5636 (2010).

21 D. Štreimikiene, J. Šliogeriene, and Z. Turskis, Renew. Energy 85, 148 (2016).

22 A. I. Chatzimouratidis and P. A. Pilavachi, Energy Policy 37, 778 (2009).

23 S. Hirschberg, R. Dones, T. Heck, P. Burgherr, W. Schenler, and C. Bauer, Sustainability of Electricity Supply Technologies under German Conditions: A Comparative Evaluation (2004)

24 S. J. W. Klein and S. Whalley, Energy Policy 79, 127 (2015).

25 E. L. La Rovere, J. B. Soares, L. B. Oliveira, and T. Lauria, Renew. Sustain. Energy Rev. 14, 422 (2010).

26 S. Genoud and J. B. Lesourd, Int. J. Green Energi 6, 257 (2009).

27 I. Rodríguez-Serrano, N. Caldés, C. de la Rúa, and Y. Lechón, J. Clean. Prod. 149, 1127 (2017).

28 G. Dorini, Z. Kapelan, and A. Azapagic, Clean Technol. Environ. Policy 13, 133 (2011).

29 A. Maxim, Energy Policy 65, 284(2014).

30 J. J. Wang, Y. Y. Jing, C. F. Zhang, and J. H. Zhao, Renew. Sustain. Energy Rev. 13, 2263 (2009).

31 H. Meyar-Naimi and S. Vaez-Zadeh, IEEE Trans. Energy Convers. 28, 327 (2013).

32 K. Kowalski, S. Stagl, R. Madlener, and I. Omann, Eur. J. Oper. Res. 197, 1063 (2009).

33 L. Stamford and A. Azapagic, Energy Sustain. Dev. 23, 194 (2014).

34 R. Brizmohun, T. Ramjeawon, and A. Azapagic, J. Clean. Prod. 106, 565 (2015).

35 R. Garcia, P. Marques, and F. Freire, Appl. Energy 134, 563 (2014).

36 P. D. I. KLHK, Regulation Regarding Life Cycle Assessment Training Materials for PROPER (Director General of Pollution and Environmental Damage Control, Indonesia, 2018) (available in Bahasa Indonesia only) 